\title{
STRATEGI INOVASI PRODUK PADA INDUSTRI KREATIF MINANGKABAU UNTUK MENGATASI PENGANGGURAN DI SUMATERA BARAT
}

\author{
Lola Fitria Sari
}

\section{PENDAHULUAN}

Ekonomi Kreatif sangat penting dikembangkan di tengah pertumbuhan ekonomi nasional yang stagnan pada kisaran 5-6 persen dalam beberapa tahun terakhir. Pengembangan ekonomi maupun industri kreatif juga akan mendorong penciptaan lapangan kerja baru, mengurangi jumlah penduduk miskin dan mendorong daya saing industri Indonesia dalam menghadapai penerapan masyarakat Ekonomi ASEAN (MEA) dipenghujung tahun 2015 lalu. Beberapa kendala mendasar dalam pengembangan industri kreatif di Tanah Air. Pertama, minimnya komunikasi antara lembaga pendidikan dan universitas dengan pelaku industri kreatif yang pada akhirnya membuat kualitas industri kreatif Indonesia belum memuaskan. Kedua, pelaku industri kreatif tak menguasai jalur distribusi. Produk-produk lokal yang sudah siap dijual, sulit didistribusikan dikarenakan ada beberapa jalur distribusi mematok dana deposit terlalu tinggi dan juga adanya preferensi standar ganda untuk produk lokal. Ketiga, buruknya regulasi. Bebasnya pergerakan perusahaan-perusahaan asing berbasis industri kreatif di Indonesia menimbulkan berbagai masalah bagi industri lokal seperti, persaingan jasa, pencarian tenaga kerja, dan akses ke pasar yang lebih dikuasai perusahaan asing. Keempat, minimnya pendanaan. Industri kreatif di Indonesia belum mendapat dukungan dana besar dari pemerintah dibandingkan dengan Jepang, Korea, Thailand maupun Malaysia, dan yang terakhir adalah kurangnya Inovasi Produk industri kreatif terutama produk kerajinan tradisional yang masih kurang beradaptasi dengan selera atau trend masa kini. Masalah-masalah ini harus segera dicari solusinya agar daya saing industri kreatif kuat dan mampu memenangkan kompetisi pada penereapan Komunitas Ekonomi ASEAN, sebagai contoh Produk kerajinan tradisional Minangkabau yaitu Sulaman, Bordiran, kain tenun, songket dan sebagainya yang masih dirasa sulit sekali untuk menembus pasar dunia.

PEMBAHASAN 
Menurut UK Department of Culture, Media, and Sports (UK DCMS), departemen yang mengurus industri kreatif di Inggris, industri kreatif adalah "those activities which have their origin in individual creativity, skill and talent and which have the potential for wealth and job creation through the generation and exploitation of intellectual property" atau jika di terjemahkan "aktivitas yang mempunyai asal dari kreativitas, kemampuan, dan bakat individu yang mempunyai potensi kekayaan dan penciptaan lapangan kerja melalui pembuatan dan eksploitasi dari kekayaan intelektual". Industri kreatif bisa dibagi menjadi banyak bagian, sebagai contoh periklanan, musik, kerajinan tangan, fashion, konten-konten digital, dan lain-lain. Industri kreatif mengandalkan ide dan kreativitas individu. Sehingga modal banyak dan mesin berlimpah tidak sepenuhnya diandalkan di industri kreatif ini. Industri kreatif bisa dibilang punya potensi yang besar. Di pasar internasional sendiri misalnya, 50\% dari belanja masyarakat (consumer spending) di negara-negara G7 (Kanada, Perancis, Jerman, Jepang, Italia, Amerika Serikat, dan Britania Raya) digunakan untuk membeli produk-produk dari industri kreatif. Sementara di dalam negeri, menurut McKinsey Global Institute, Indonesia mempunyai kurang lebih 45 juta konsumen aktif dan diperkirakan bisa mencapai 135 juta pada tahun 2030. Ditambah dengan populasi anak muda di kaum urban yang kian bertambah, seharusnya industri kreatif bisa berkembang pesat di kalangan anak muda karena anak muda sering mengonsumsi produk-produk kreatif seperti musik, konten-konten digital, dan fashion. Di Indonesia, industri kreatif memegang peranan yang bisa dibilang cukup penting untuk produk domestic bruto (PDB) Indonesia. Industri kreatif merupakan industri dengan kontribusi ke 7 terbesar dari 10 sektor ekonomi yang ada. Menurut data Kementerian Pariwisata dan Ekonomi Kreatif (Kemenparekraf), pada tahun 2013 industri kreatif dapat berkontribusi terhadap produk domestic bruto (PDB) sebanyak 7,29\% atau senilai 486,1 triliun. Kontribusi ini meningkat dibandingkan tahun 2-12 dimana industri kreatif dapat berkontribusi untuk PDB Indonesia sebanyak 6,9\% meskipun nilainya 573,89 triliun rupiah. Tapi tetap saja peranan industri kreatif semakin bertambah. Industri kreatif juga dapat menyerap tenaga kerja sebanyak 11,8 juta atau 10,72\% dari total tenaga kerja di Indonesia pada tahun 2013. Hal ini cenderung meningkat dibandingkan tahun 2012 dimana industri kreatif dapat menyerap 8,6 juta tenaga kerja atau $7,9 \%$ dari total tenaga kerja di Indonesia pada tahun 2012. Meskipun dengan 
kontribusi yang cukup besar, tetapi banyak masalah yang terjadi dalam pengembangan industri kreatif ini. Ditambah lagi dengan masalah pembajakan kekayaan intelektual. Menurut International Intellectual Property Alliance atau IIPA, Indonesia ditempatkan dalam daftar pengawasan prioritas bersama dengan negara-negara lain seperti Cina, India, dan Thailand. Pembajakan ini membuat kerugian yang sangat besar. Menurut data United States Trade Representative tahun 2012, total kerugian yang dicapai Indonesia akibat pemalsuan dan pelanggaran hak cipta mencapai US\$ 1 triliun dan menghilangkan lapangan pekerjaan untuk 2 juta orang. Hal itu diperparah dengan kurangnya kesadaran para seniman dalam memperjuangkan Hak Kekayaan Intelektual atau HaKI. Selain itu, masalah infrastruktur seperti akses internet yang kurang merata bisa menjadi hambatan untuk mengembangkan industri kreatif, terutama industri konten-konten digital yang membutuhkan akses internet. Teknologi yang kurang pun bisa membuat industri kreatif terhambat dan akhirnya akan mempunyai kelemahan yang bisa dijadikan keunggulan oleh produk sejenis dari luar negeri. Sebagai contoh, batik imitasi dari China memakai teknologi modern yang hasilnya bisa lebih murah dibandingkan batik yang dibuat dengan tangan. Masyarakat dewasa ini mengalami perubahan yang sangat cepat dan komplek, karena kemajuan ilmu dan teknologi. Perubahan menyeluruh terjadi hampir pada semua aspek kehidupan. Pasar kerja berubah drastis, baik yang disebabkan pengaruh informasi maupun teknologi global. Perubahan yang begitucepat membawa dampak terhadap tuntutan masyarakat. Dampak perubahan tersebut menuntut adanya perubahan dalam pola dan strategi pengelolaan kelembagaan yang lebih sesuai, sehingga dapat memberikan respon yang tepat terhadap tantangan yang ada. Demikian halnya yang terjadi dalam pada pengelolaan Unit Produksi Kerajinan tradisional dibutuhkan usaha dalam rangka mengembangkannya. Tuntunan Inovasi produk atau pengembangan produk serta mutunya sangat dibutuhkan. Pengembangan produk (produck development), pada dasarnya adalah upaya perusahaan untuk senantiasa menciptakan produk baru, memperbaiki produk lama agar dapat memenuhi tuntutan pasar dan selera pelanggan. Keinginan untuk melakukan pengembangan produk dan jasa pelayanan sangat tergantung pada strategi bisnis yang dapat diterapkan untuk pengembangan produk dan jasa, yaitu strategi biaya rendah, (lowcost), strategi segmentasi pasar (market segmentation) dan strategi product differentiation. Apapun strategi bisnis yang dimiliki oleh industri, inovasi produk sangat diperlukan. Unit produksi sebagai suatu usaha yang dapat mengembangkan income generating, bisa mencapai tujuannya apabila selalu 
berusaha untuk memberikan produk dan jasa pelayanannya sesuai dengan keinginan pelanggan. Tuntutan dan keinginan pelanggan selalu berkembang sejalan dengan perkembangan ilmu pengetahuan, teknologi dan informasi, karena itu mengembangkan produk, termasuk di dalamnya diversifikasi produk merupakan tantangan tersendiri yang harus diupayakan. Pelanggan membutuhkan produk yang senantiasa baru dan spesifik. Untuk mewujudkan hal tersebut diperlukan inovasi yang terus menerus sehingga unit produksi sebagai usaha akan terus hidup dan berkembang. Kehadiran industri kreatif memberikan peluang bagi pengelola perguruan tinggi untuk memperlengkapi para mahasiswanya untuk dapat mau dan mampu bersaing sesuai dengan tuntutan pasar (Togar: 2007). Ada kecenderungan bahwa pengangguran terdidik terus meningkat sejak tahun 2003. Kontribusi PT setiap tahunnya sekitar 5-7\% dari jumlah total penganggur. Sudah menjadi perdebatan awam bahwa lulusan PT sudah seharusnya berani menciptakan lapangan kerja dan bukan memburu pekerjaan. Lulusan PT sebaiknya sudah dipersiapkan sejak berada di bangku kuliah untuk mengenal medan laga industri kreatif yang penuh dengan risiko tetapi dengan imbalan yang luar biasa. Semangat kewirausahaan sudah harus ditumbuhkan untuk mengenal dan menangkap peluang yang ada dan bukan di saat para lulusan memasuki dunia kerja. Lulusan yang cenderung bekerja di sektor formal bukan karena mereka tidak mampu menjadi pewirausaha tetapi mereka tidak memperoleh kesempatan untuk berlatih dan berlaga di medan industri kreatif. Hasil Sakernas semester pertama 2007 menunjukkan hanya satu dari empat lulusan perguruan tinggi yang memilih pewirausaha. Sementara mayoritas lulusan ingin bekerja pada orang lain sebagai karyawan atau buruh pada perusahaan dengan menerima upah atau gaji rutin. Sudah menjadi perdebatan awam bahwa lulusan PT sudah seharusnya berani menciptakan lapangan kerja dan bukan memburu pekerjaan. Upaya pengembangan produk pada kegiatan unit produksi kerajinan tradisional di PT ini dimungkinkan untuk memberikan kesempatan pada mahasiswa dalam menangkap peluang pasar, mengembangkan kreativitas dalam mengembangkan produk dan bersaing di industri kreatif.

\section{Strategi Inovasi Produk Kerajinan Tradisional}

Setiap perusahaan harus selalu mengembangkan produk baru. Produk pengganti harus diciptakan untuk mempertahankan atau membangun penjualan. Selain membangun penjualan pelanggan juga menginginkan produk baru dan para pesaing akan berusaha keras untuk memenuhinya. Suatu perusahaan dapat menambah produk baru melalui 
inovasi produk. Inovasi produk baru dapat dilakukan melalui dua cara yaitu : (1) mengembangkan produk baru di laboratorium sendiri atau, (2) membuat kontrak dengan peneliti independen atau perusahaan pengembangan produk baru untuk mengembangkan produk khusus bagi perusahaan. (Philip Kotler, 1997-273). Adanya tingkat persaingan yang sangat ketat saat ini, perusahaan yang tidak mengembangkan produk baru akan menghadapi resiko yang sangat besar. Produk yang telah ada sangat rentan terhadap perubahan kebutuhan dan selera konsumen, teknologi baru, siklus hidup produk yang lebih singkat dan meningkatnya persaingan. Beberapa kecenderungan yang mungkin terjadi di bidang pengembangan produk seiring dengan adanya beberapa kecenderungan akibat globalisasi, yaitu: (1) Proses pengembangan produk yang lebih baik, lebih canggih, lebih berkualitas, lebih murah dibandingkan dengan produk sebelumnya akibat dari perubahan teknologi yang sangat cepat, (2) Perubahan produk dituntut untuk menjadi unggulan baik dalam arti komparatif maupun kompetitif. Kecenderungan tersebut perlu diantisipasi dalam melakukan strategi pengembangan produk yang melihat perspektif secara keseluruhan, baik dalam hal fasilitas produksi, sumberdaya manusia, desain produk, teknologi proses, efisiensi, produktifitas, kapasitas, kecepatan respon maupun fleksibilitas. Dalam menetapkan dan menyusun strategi pengembangan produk, produsen dihadapkan pada beberapa tantangan antara lain: (1) makin terbatasnya gagasan tentang produk baru. Cepatnya perubahan tuntutan pasar tidak selalu dapat diimbangi dengan munculnya gagasan utuk menciptakan produk baru, (2) Pasar yang makin terkotak-kotak (fragmented markets). Persaingan yang semakin tajam mengakibatkan pasar yang semakin sempit, (3) Produk baru lebih dituntut untuk memenuhi persyaratan keamanan konsumen dan lingkungan hidup, (4) Mahalnya proses pengembangan produk, (5) Usia produk yang seakin singkat. (PhilipKotler, 1997: 274). Upaya mengatasi tantangan serta mencegah kemungkinan terjadinya kegagalan, strategi pengembangan produk dan pelayanan harus dirumuskan sejalan dengan strategi pemasaran perusahaan jangka panjang dan bukan keputusan yang impulsive atau mendadak. Strategi merupakan alat untuk mencapai tujuan dengan dukungan yang optimal dari sumberdaya yang dimiliki.

Empat macam pendekatan yang dapat ditempuh dalam menetapkan strategi inovasi/ pengembangan produk adalah (1) Membuat satu atau beberapa produk baru. (2) Membuat model baru dari produk lama atau menyempurnakan produk lama sehingga 
bentuk/penampilannya lebih menarik dan baik mutunya. (3) Menambah citra dan manfaat produk dan (4) Diversifikasi produk. (Pendidikan Manajemen Multimedia, 2000) . Strategi pengembangan produk dapat dilaksanakan melalui beberapa tahapan yaitu:

1. Pemunculan gagasan; dimulai dari pencarian gagasan dan pada tahap ini harus mendifinisikan produk dan pasar yang ingin ditekankan dan harus menyatakan tujuan produk baru tersebut. Gagasan produk baru dapat diperoleh dari beberapa sumber antara lain: pelanggan, pegawai, ilmuwan, pesaing, saluran pemasaran ataupun dari manajemen sendiri.

2. Penyaringan gagasan; banyak gagasan yang bisa diambil yaitu dengan mengorganisasikan secara baik. Selanjutnya gagasan-gagasan ditelaah untuk mendapatkan gagasan yang baik dan sesuai dengan yang diharapkan.

3. Pengembangan dan pengujian konsep; gagasan yang menarik selanjutnya disempurnakan menjadi konsep produk yang dapat diuji. Pada tahap ini kita bisa membedakan antara gagasan produk, konsep produk dan citra produk.

4. Pengembangan strategi pemasaran; setelah pengujian langkah selanjutnya adalah mengembangkan suatu rencana awal strategi pemasaran untuk memperkenalkan produk baru ke pasar. Strategi pemasaran akan mengalami penyempurnaan lebih lanjut pada tahap berikutnya.

5. Analisis bisnis; setelah mengembangkan konsep produk dan strategi pemasaran, selanjutnya dapat mengevaluasi daya tarik bisnis. Diperlukan banyak proyeksi penjualan, biaya dan laba untuk menentukan apakah sudah sesuai dengan tujuan. Jika memenuhi dapat dilanjutkan ke tahap pengembangan produk.

6. Pengembangan produk; jika konsep produk dapat melewati uji bisnis maka selanjutnya dikembangkan menjadi suatu produk fisik.

7. Pengujian pasar; setelah kinerja fungsional dan psikologis produk sesuai yang diharapkan, produk siap untuk didandani dengan merek, kemasan dan program pemasaran awal. Tujuannya untuk menguji produk dalam lingkungan konsumen yang nyata dan untuk mempelajari seberapa besar pasar itu dan bagaimana konsumen dan penyalur bereaksi untuk menangani, menggunakan dan membeli kembali produk aktual.

8. Komersialisasi; pengujian pasar kemungkinan memberikan cukup informasi untuk memutuskan dapat tidaknya meluncurkan produk baru itu. Jika perusahaan meneruskan 
dengan komersialisasi akan membutuhkan biaya yang besar. (Philip Kotler, 1997:277-295).

Berdasarkan pendapat Kotler tersebut upaya pengembangan / inovasi produk pada kegiatan di unit produksi kerajinan tradisional secara riil dapat dilakukan meliputi tahapan berikut ini :

1. Pengembangan gagasan, pada tahap ini terlebih dahulu dilakukan identifikasi dan pengembangan gagasan yang dilakukan secara sistematik, sehingga dapat dihindari gagasan yang tidak relevan dan tidak realistis.

2. Penyaringan gagasan. Tujuan dari penyaringan gagasan adalah untuk mengurangi gagasan yang ada agar benar-benar dapat diwujudkan, sesuai dengan kebijakan dan strategi perusahaan. Penyaringan gagasan ditentukan melalui kesepakatan usaha yaitu (1) standar organoleptik yang meliputi warna, bahan, desain penampilan yang disukai oleh panelis. (2) mempunyai keunikan atau ciri khas, artinya produk tidak dijual dipasaran. (3) teknik olah tidak rumit, mengingat akan diproduksi dalam jumlah banyak.dan (4) bahan tersedia di pasaran.

3. Pengembangan dan Uji Konsep. Pada tahap ini gagasan yang telah disetujui kemudian dikembangkan menjadi konsep produk. Konsep produk tersebut divalidasi oleh pakar-pakar di bidang fashion.

4. Analisis Biaya. Pada tahap ini dilakukan evaluasi terhadap keseluruhan rencana pengembangan, terutama yang berkaitan dengan kelayakan harga jual. Perhitungan biaya menggunakan metode mark up yang bertujuan untuk mengetahui berapa produk yang terjual dengan keuntungan yang kita inginkan. Keuntungan dapat diperoleh dengan adanya kenaikan biaya produk yang dibuat. Kenaikan yang ditemukan seharusnya dapat menutupi biaya tetap, biaya variable dan mencakup laba yang diinginkan.

Rumus harga jual yang digunakan :

Harga jual $=$ Biaya produk + Mark Up $=$ Biaya produk $+(\% \times$ Biaya produk $)$

Harga jual $=$ Biaya $(1-\%$ Mark Up)

Sedang untuk menghitung titik impas menggunakan BEP (Break EvenPoint), dengan menggunakan rumus:

$\mathrm{TBE}($ unit $)=\mathrm{BTT}$

H-BVR 
Keterangan : TBE $=$ Titik Break Even Point

BTT $=$ Biaya tetap total

$\mathrm{H}=$ Harga Jual Per Unit

$\mathrm{BVR}=$ Biaya variabel rata-rata

Produk yang dihitung harga jualnya adalah yang telah melalui uji konsep.

5. Pengembangan dan Uji Produk. Pada pengujian produk, dilakukan uji organoleptik oleh panelis terlatih. Produk yang diuji untuk menguji tingkat kesukaan dengan metode hedonic test pada sampel produk yang diujikan. Pengujian ini mengkaji tingkat kesukaan panelis terhadap produk yang dihasilkan. Panelis diminta menilai sampel produk berdasarkan kesenangannya, menurut skala yang nilai yang sudah ditentukan. Kriteria penilaian menggunakan skala nilai berkisar 1 sampai 4. Kriteria penilaian 1 untuk sangat disukai, nilai 2 disukai, nilai 3 tidak disukai dan nilai 4 sangat tidak disukai. Produk yang akan diujikan diberi kode sesuai dengan jenis pengujiannya. Skope uji kesukaan meliputi bahan, warna, desain dan bentuk masing-masing sampel produk yang dihasilkan.

6. Perumusan Produk yang dihasilkan menjadi rancangan standar, yang siap diimplementasikan, sebagai hasil dari seluruh kegiatan pengembangan produk. Riset dan pengembangan yang dilakukan oleh perguruan tinggi dalam hal ini pengembangan atau inovasi produk pada kegiatan produksi kerajinan tradisional minangkabau pada intinya merupakan merupakan salah satu bagian dari klaster industri kreatif, seluruh aktivitas riset dan pengembangan pada dasarnya adalah unsur dari kreativitas, yang pada akhirnya menjadi produk-produk sesuai dengan kebutuhan-kebutuhan pasar Industri kreatif melibatkan akademisi, Du/Di, dan pemerintah yang juga dikenal dengan triple helix. Keterlibatan 3 unsur tersebut pada dasarnya merupakan kerjasama yang saling sinergi, berinteraksi untuk menghasilkan suatu produk produk kreatif yang mempunyai nilai ekonomi. Sebagai contoh disebutkan, seorang akademisi atau peneliti melakukan kreasi-kreasi dengan melakukan riset dan pengembangan menghasilkan suatu inovasi produk-produk industri, kemudian pihak Du/Di atau pemerintah juga harus melihat, apakah kreatifitas atau inovasi tersebut mempunyai nilai secara ekonomis . Dalam hal itu, Du/Di akan segera bisa mengambil kreasi-kreasi dari akademisi tersebut sejauh pasar-pasar membutuhkan, kemudian dari sisi lain pihak pemerintah bertindak dengan memberikan fasilitas, sehingga ada interaksi antara kreator atau innovator/periset berhubungan dengan pihak Du/Di. Dengan demikian jika interaksi tersebut bisa berjalan 
dengan baik maka produk-produk kreatifitas akan tumbuh dan mempunyai nilai-nilai ekonomi. Proyek bersama berbisnis kreatif dari masyarakat melalui produksi kerajinan tradisional perlu diperkenalkan dan didorong agar terjadi secara alamiah karena adanya kebutuhan dan tanggung jawab dari diri masyarakat untuk dapat mempersiapkan dirinya menghadapi persaingan pasar yang lebih ketat.

Pemerintah juga harus memastikan perlindungan terhadap industri kreatif semakin kuat, memacu proteksi melalui pendekatan indikasi geografis. Indikasi geografis adalah bagian dari hak kekayaan intelektual yang terdiri dari tiga kategori yaitu produk hasil alam atau kekayaan alam, produk hasil pertanian dan produk-produk kerajinan tangan atau hasil industri. "Untuk lebih mudah dipahami, pada prakteknya indikasi geografis ini dilekatkannya nama lokasi di mana sebuah produk diproduksi atau terkait lokasi yang identik dengan produk. Dalam konteks pemasaran, biasanya untuk memperkuat identifikasi serta memperkuat branding, Contohnya, antara lain Songket Silungkang, Selendang Koto Gadang, Kopi Bukik Apik, Kerupuak Sanjai, Nasi Kapau, Sulaman Ampek angkek dan lain-lain. Perlindungan ini tak lepas dari hasil industri kreatif termasuk didalamnya kerajinan tangan memiliki potensi yang besar dilihat dari jumlah unit usaha dan persebarannya di Indonesia. sekarang nama-nama lokasi itu tidak sekadar untuk kepentingan pemasaran atau identifikasi produk tapi lebih jauh lagi yaitu perlindungan. Riilnya, manfaat indikasi geografis akan bermanfaat bila telah diajukan pendaftaraan, antara lain dapat melindungi produsen dari kemungkinan pemalsuan produk, dan memberi jaminan kualitas produk yang berlabel indikasi geografis sebagai produk asli.

\section{Penutup}

Industri Kreatif adalah industri yang unsur utamanya adalah kreativitas, keahlian dan talenta yang berpotensi meningkatkan kesejahteraan melalui penawaran kreasi intelektual. Industri kreatif terdiri dari penyediaan produk kreatif langsung kepada pelanggan dan pendukung penciptaan nilai kreatif pada sektor lain yang secara tidak langsung berhubungan dengan pelanggan. Upaya inovasi dan kreativitas, melalui pengembangan produk pada kegiatan produksi kerajinan ini menjadi salah satu upaya untuk memenuhi kebutuhan pelanggan. Pelanggan membutuhkan produk yang senantiasa baru dan spesifik. Untuk mewujudkan hal tersebut diperlukan inovasi yang terus menerus sehingga unit 
produksi sebagai usaha akan terus hidup dan berkembang menunjang industri kreatif, dan pengangguran pun dapat diminimalisir. Dengan demikian, peran PT menjadi penting sebagai basis produksi, diseminasi, dan aplikasi ilmu pengetahuan serta inovasi teknologi.

\section{Daftar Pustaka}

....................Direktorat Pendidikan Menengah Kejuruan. (1994), Buku Pedoman Penyelenggaraan Unit Produksi SMK. Jakarta : Depdikbud.

Philip Kotler, Gary Amstrong. 1997. Dasar-dasar Pemasaran Jilid ke 1, Alih Bahasa Alexander Sindoro. Jakarta: Prehalindo.

Philip Kotler,1997. Marketing Manajemen.Analisys, Planning, Implementation and Control,. USA : Printice-Hall.

Slamet PH. (1996). Pendidikan Unit Produksi Studi Pengembangan Bisnis Manajemen (SMEA) di Indonesia. Yogyakarta: FPTK IKIP Yogyakarta.

Subijanto, (2004), Teori Harga Faktor Produksi Ekonomi Makro, Yogyakarta.

Togar M. Simatupang. (2007). Perkembangan Industri Kreatif. Makalah disampaikan pada Dinas Perindustrian dan Perdagangan Jawa Barat. 